\title{
academicjournals
}

Vol. 10(4), pp. 154-160, April 2018

DOI: $10.5897 / I J B C 2017.1162$

Article Number: FBF3AD756278

ISSN 2141-243X

Copyright (c) 2018

International Journal of Biodiversity and

Author(s) retain the copyright of this article

Conservation

http://www.academicjournals.org/IJBC

\section{Mammalwatching: A new source of support for science and conservation}

\author{
Vladimir Dinets $^{1,2^{\star}}$ and Jon Hall ${ }^{2}$ \\ ${ }^{1}$ Okinawa Institute of Science and Technology, 1919-1 Tancha, Onna-son, Kunigami-gun, Okinawa, 904-0495, Japan. \\ ${ }^{2}$ Department of Psychology, University of Tennessee, Knoxville, TN 37996, USA.
}

Received 27 October, 2017; Accepted 18 February, 2018

\begin{abstract}
During the 20th century, birding evolved from a little-known hobby into a global phenomenon important for ornithology and bird conservation. More recently a similar change has begun for mammalwatching, which is rapidly gaining popularity and is already providing financial support, observational data, diagnostic information, and a volunteer base for mammalogy and mammalian conservation. The study data suggest that mammalwatching has the potential to end decades of neglect of small mammals in dire need of conservation, to improve our knowledge of mammalian status and distribution, and to increase public support for conservation measures, especially for species not seen as particularly charismatic by the general public. Professional mammologists and conservation workers can benefit from this new trend, but they can also help it. We offer a number of suggestions as to how professionals mammalogists and the amateur community can better work together to promote conservation and science.
\end{abstract}

Key words: Amateur naturalists, biodiversity, citizen science, ecotourism, mammalogy, mammals, volunteering.

\section{INTRODUCTION}

A century ago, watching birds was a little-known hobby, practiced by a small number of people who might be described today as "geeks" (Moss, 2004). There were no pocket-size field guides, and many bird species were believed to be indistinguishable in the wild (Dunlap, 2011). Only professional ornithologists with access to large museum collections were trusted with identifying birds (Moss, 2004). But things gradually changed. Now birding is, along with other forms of wildlife-based tourism, among the fastest growing tourism sectors in the world (Sekercioglu, 2002; Balmford et al., 2009; Cordell and Herbert, 2012).

There are hundreds of thousands, perhaps millions of birders worldwide (La Rouche, 2003). More than a

*Corresponding author. E-mail: dinets@gmail.com. Tel: 404-41 4-6539; 080-1 155-4373.

Author(s) agree that this article remains permanently open access under the terms of the Creative Commons Attribution License 4.0 International License 
quarter of a million people use the eBird software (developed by the Cornell Ornithology Lab to help birders record their sightings) to record bird sightings., and you can find lively birding communities in places like Moscow, Delhi, Mexico City, and Cape Town (de Silva and Reyes, 2010).

Birding has largely replaced destructive activities such as collecting bird eggs and mounted birds (Dunlap, 2011). It creates a wealth of data for ornithologists, incentives for protecting rare bird species, and a market for bird books (Greenwood, 2007). Data from eBird has been used in over a hundred scientific papers in the first five years since its launch in 2004 (Sullivan et al., 2009; website ebird.org for bibliography).

Some communities located in particularly "birdy" locations now receive much of their income from birdwatching tourism, and invest considerably in bird conservation (Sekercioglu, 2002). Such places include Mindo in Ecuador, Fraser's Hill in Malaysia, Tippi in India, and Wundanyi in Kenya (VD pers. obs.). Bialowieza in Poland gets 15 times more income from visiting birders than from logging (Czeszczewik and Walankiewicz, 2017). Even the most cryptic, obscure, hard-to-identify bird species receive considerable public attention if they are in need of conservation (see, for example, Hirschfeld et al., 2013; Hosner et al., 2013). In addition, birders form a sizeable pool of volunteers for various scientific projects, often contributing their money as well as manpower.

Mammalwatching today is arguably where birdwatching was a century ago. In many countries there are few - if any - comprehensive field guides for mammals, and the existing books often include only larger species. Many species are thought to be identifiable only if caught, or only in a genetics lab (Whitaker, 1996).

"Mammal finding" guidebooks are even scarcer than identification guides: the first guidebook devoted specifically to finding all North American mammals in the wild wasn't published until 2015 (Dinets, 2015), the first one for Australia appeared in 2016 (Andrew 2016), and there is still, to our knowledge, no such book for many parts of Europe or any part of Asia (bird-finding guides exist for all continents, many countries, and some states and provinces).

However in the last few years, the popularity and scope of mammalwatching has begun to grow noticeably worldwide. People are discovering that the hobby can be as rewarding as birding, with many (perhaps even more) diverse experiences and challenging adventures involved in seeing wild mammals (Dinets, 2015). Mammalwatching.com is probably the leading website for the amateur mammalwatcher, sharing trip reports and other relevant information. Its popularity has grown steadily from near-zero a few years ago: site traffic reports show that, for instance, the website has about
2,500 active users each month, while its forum page received almost 70,000 visitors from 136 countries in 2014. The Australian Mammal Watching group on Facebook has around 1,500 members and is very active.

In Africa, where watching large mammals has have been a tourist attraction for decades, smaller species are now increasingly sought by tourists and their guides (Novacovic and Das, 2006). In addition, the proportion of birders who pay attention to mammals and include data on mammal sightings in their trip reports is growing; an informal survey of 200 trip reports from the most popular birdwatching sites has shown that the share of reports containing information on mammals has grown from 5\% in 1990 to $55 \%$ in 2014 (VD unpublished, 2015).

Does this sudden change have a potential to aid research and conservation of mammals in the same way birding aids research and conservation of birds? This is an important question because such aid is direly needed. The apparent lack of public knowledge or interest for many species of smaller mammals, particularly tropical ones, might well contribute to their seeming neglect by conservation organizations and ministries.

For example, less than $1 \%$ of small South American mammals have ever been the focus of any conservation measures (IUCN, 2014). Critically important patches of small mammal habitat are being lost with no - or virtually no - attempts from the conservation community to save them; recent examples include high-altitude forests of Sierra de Cuchumatanes in Guatemala (Matson et al., 2012) and Lake Khasan meadows in Russia (Newell, 2015).

Moreover, scientific knowledge of many species is limited when compared to birds: the IUCN lists 799 species of mammals, or $14.7 \%$ of the total number, as data deficient, compared to just 62 species of birds, or $0.6 \%$ of the total (IUCN, 2014).

Below we present evidence that mammalwatching is already making a positive impact on science and conservation, and that its impact can be greatly increased if mammalwatching is more widely known, recognized as beneficial, and assisted.

\section{Beneficial effects of mammalwatching}

Mammalwatching has a number of benefits - both indirect and direct - for the scientific community and broader wildlife conservation.

\section{Public awareness}

Just like other kinds of nature-based tourism, mammalwatching helps bridge the growing disconnect 
between people and the natural environment (Balmford et al., 2009). Many amateur mammalwatchers are urban residents: for example, among 100 randomly chosen subscribers of Australian Mammalwatching Facebook group who had their residential information listed, 98 lived in cities (VD unpublished 2017). And greater public interest in nature helps pave the way to greater public support for studying it (Novacek, 2008). Local communities are often proud of the attention that even a few mammal-seeking visitors can bring to their area. Knowing that an animal is important to the outside world can provide the impetus for local people to save a species, even if it the tourism dollars do not cover their costs of doing so. 25 years after a visit by three mammalwatchers, local residents of remote Evoron Village in Russia were still aware of the importance of the local endemic, the Evoron vole (Microtus evoronensis), and limited annual burning of grass in its habitat (M. Sanchez personal communication).

\section{Eco-tourism revenue}

Certain forms of mammal-based tourism, including the safari industry and whale watching, already generate significant revenue. Game watching is probably best established in parts of eastern and southern Africa.

Although it has been focused on larger mammals, as evidenced by the fact that most field guides to African mammals cover smaller mammals only briefly or not at all (Dinets, 2015), it has become the backbone of local tourism in some areas and has generated substantial revenue (Christie and Crompton, 2001; Higginbottom, 2004). In southern Africa, nature-based tourism now generates roughly the same revenue as farming, forestry, and fisheries combined (Scholes and Biggs, 2004).

The money spent by mammal watchers is modest in comparison to that spent on the safari industry in general, but it can still have an important impact. Hundreds of people now visit Ladakh each winter to try to see a Snow Leopard. A cottage industry, employing numerous guides, spotters, porters and cooks, has sprung up as a result, and the leopards are better monitored and protected than ever (Desai, 2016).

But when we talk about mammalwatching, we talk about an interest in mammals that goes beyond charismatic megafauna, to include smaller and rarer species than the Big Five or baleen whales. As mammalwatchers become increasingly interested in small mammals, they more often visit locations outside established tourist routes. Even a handful of visitors to such remote places can be enough to generate livelihoods and promote greater interest in - and awareness of - wildlife conservation among the local population. For example, in a country like Sierra Leone, where Gross National Income per capita is less than $\$ 500$ (World Bank, 2017), and average income in rural areas is almost certainly much lower, a few mammalwatchers spending a week in a remote area like Gola Forest (where a few rare mammals occur) can make a noticeable contribution to the local economy $(\mathrm{JH}$ pers. obs.).

\section{Obtaining scientific data}

In addition to generating revenue, providing incentives for local conservation, and generally stimulating interest in nature, mammalwatching creates other direct benefits for conservation and science.

Mammalwatching in Africa produces a wealth of data, including extensive amateur databases and numerous contributions to the Mammals Atlas project (mammalMAP) coordinated by the Animal Demography Unit at the University of Cape Town (http://adu.org.za) (R. Primack personal communication). In Australia, the Dryandra Group is maintaining a database of numbat (Myrmecobius fasciatus) sightings and campaigning for creating a national park in the area (www.facebook.com/groups/dryandra/).

Amateur mammalwatchers combine their resources to organize research expeditions, and provide data for professional researchers. Distributional records recently obtained by amateur mammalwatchers (including participants of specialized mammalwatching tours) include the first documented record of Pousargues' mongoose (Dologale dybowskii) in Uganda since the 1970s (Woolgar, 2014), the rediscovery of the Javan small-toothed palm civet (Eaton et al., 2010), the first records of two species of Vulpes foxes from northeastern Ethiopia (Dinets et al., 2015), the first documented sighting of Arunachal macaques (Macaca munzala) in Kaziranga National Park (A. C. Smith in prep.), the first documented records of Altai weasel (Mustela altaica) in Ladakh by the members of a 2014 mammalwatching expedition (Ben-Yehuda, 2018), and a significant portion of recent records of rare cetaceans (Wilson and Mittermeier, 2014). Data from amateur mammalwatchers were being used to determine the distribution of the recently described olinguito (Bassaricyon neblina) (K. Helgen personal communication), and to obtain the first data on the longevity of the spectral bat (Vampyrum spectrum) in the wild (Dinets, 2016).

Other contributions include a unique record of multiple groups of humpback whales (Megaptera novaeangliae) taking turns disrupting attempts by killer whales (Orcinus orca) to hunt California sea lions (Zalophus californianus) (Pitman et al., 2017), and multiple records used in a study of surface foraging by Scapanus moles (Dinets, 2017). 
In 2016 to 2017, two potential new species have been discovered by mammalwatching tour groups: a penciltailed mouse (Chiropodomys) in Sri Lanka (Reid in prep.) and a harvest mouse (Reithrodontomys) in Nicaragua (Martinez et al. in prep.).

Data collected by amateurs can be as reliable as data collected by professional zoologists (Kylie et al., 2014). Indeed, just as in birdwatching, the line between amateurs and professionals is increasingly blurry, with amateurs now submitting their data directly to scientific journals, and professional biologists enjoying mammalwatching in their spare time and contributing trip reports: see, for example, trip reports by Stuart Mardsen's Conservation Research Group at Manchester Metropolitan University, UK (https://stuartmarsden.blogspot.ca); by Charles Foley of the Wildlife Conservation Society in Tanzania (Foley, 2005); by Rohan Clarke of Monash University, Australia (Clarke, 2016); and by Andrew Balmford of Cambridge University (Balmford, 2013).

\section{Volunteer work}

Volunteering for research projects is a growing trend among mammalwatchers. In the USA and elsewhere, amateur mammalwatchers now regularly volunteer for bat and marine mammal research and conservation projects (Racey, 2013; Thiel et al., 2014). In the UK, amateur mammalwatchers participate in a number of long-term studies, such as Living with Mammals project (http://ptes.org/get-involved/surveys/garden/living-

mammals/), which includes rodent and roadkill surveys, and Marine Life (www.marine-life.org.uk/), a program of marine mammal studies. In Western Australia the State government's Conservation and Land Management department was able to fund mammal research trips to remote areas by charging amateur mammalogists for the privilege to volunteer (Buckley 2003). In Russia, amateur mammalwatchers now provide hundreds of man-hours of volunteer work to some nature reserves, such as Kedrovaya Pad' and Kronotsky; they are also campaigning for better protection of nature reserves ( $M$. Krechmar and S. Shpilenok personal communication). It is, therefore, arguably in the interest of professional zoologists and conservationists to encourage the growth of the mammalwatching hobby.

\section{Potential negative effects of mammalwatching}

Of course, mammalwatching is not without potential drawbacks from a conservation point of view. The popularity of birdwatching has created benefits for science and conservation, but also problems. The use of tape recordings for playback has altered bird behavior in some popular birding locations, prompting bans on playback of any animal sounds in many protected areas; disturbance by numerous visitors has been blamed for local extinctions (although this has never been proven) and increased nest failure, although the latter results more often from disturbance by photographers than by birders (Sekercioglu, 2002). There are also "secondary" negative effects such as increased greenhouse gas emission by long-distance travelers. Can mammalwatching have negative effects? Probably, if it becomes as popular as birdwatching. So far, although the hobby is growing in popularity, the number of people likely to visit any area is low and so the impact of mammalwatchers is limited (although that is not to say that some mammals are not impacted by ecotourism more generally). Also, many experienced tour guides agree that mammalwatchers tend to be "better-behaved" and less disruptive than wildlife photographers and nonnaturalists (N. Black, R. Cameron, T. Collard, B. Eligulashvili, B. Gebretsadik, M. McTurk, E. Razoanantenaina, F. Reid, N. Sfatau, B. Zuwadi, S. !Noxmias personal communication). But it will be important to develop rules and policies ensuring that the positive impacts of mammalwatching outweigh the negative ones. Some efforts to teach novice mammalwatchers ethical conduct are already ongoing: for example, Bat Conservation International runs classes on bat observation techniques (www.batcon.org), while Marine Life has courses for marine mammal observers (www.marine-life.org.uk/). The first books for mammalwatchers have chapters on responsible wildlife viewing (Estes, 1999; Moores, 2007; Dinets, 2015; Andrew, 2016).

\section{Promoting mammalwatching and improving its impact}

We have demonstrated that the growing mammalwatching community has the potential to benefit mammalogy and conservation in a number of ways including bringing money, manpower, and knowledge. How, then, can mammalogists leverage this potential to encourage the growth of responsible mammalwatching? We have a number of suggestions.

\section{More publishing}

Although some amateur mammalwatchers have published information in scientific literature as we discussed earlier, the vast wealth of data from trip reports is unpublished (JH pers. obs.). There are likely several reasons, but a lack of experience in publishing scientific 
articles is off-putting for many would-be contributors. Perhaps professional mammalogists would be willing to co-author work, primarily notes of unusual sightings, to build capacity among the amateur community and help ensure current (and future) records enter the literature. Developing some guidelines for potential authors, outlining a general format and set of criteria for publishing work, along with the names of publications, newsletters or websites which could be approached to publish such work would also be helpful. Mammalwatching.com could provide a mechanism to link the amateur and professional worlds. It seems clear that many mammalwatchers feel little incentive to publish records in anything other than trip reports (indeed many do not even write trip reports). The mammalwatching community can provide encouragement, stressing the importance of such contributions to science and also pointing out that stronger relationships with academia can help mammalwatchers: the latter frequently contact academics to ask where best to see certain species and/or to seek help with identification, and are usually met with generous assistance (JH pers. obs.).

\section{Ethical mammalwatching}

As mammalwatching grows, it is more important than ever to ensure that it is undertaken ethically. Of course, different people have different views on what is ethical: some might believe that using a spotlight to observe nocturnal species is an unnecessary disturbance; others might oppose using live traps to capture rodents for anything other than strictly scientific reasons (and indeed in some countries legislation seeks to ensure just this). Such arguments are unlikely to be resolved anytime soon, but perhaps we can agree that a guiding principle ought to be to ensure that, on balance, the mammalwatching community is doing significantly more good than harm: perhaps those spotlights are indeed disturbing lemurs in a patch of Madagascan forest, but without the income generated by the tourists holding them it is likely that the forest itself would have been lost. Whether or not mammalwatching indeed makes a positive contribution will depend on many factors, and vary from site to site and species to species. But the more experience a mammalwatcher gains in the field with professionals, the less likely he or she is to inadvertently harm an animal. Mammalwatchers have learned a great deal about many aspects of mammalogy from the academic community, particularly when volunteering to help with field work around the world, including unobtrusive wildlife observation and responsible live trapping of small mammals. And promoting similar opportunities to mammalwatchers could be a triple win for mammalwatching, resource-strapped academics, and conservation. Learning about volunteering opportunities is haphazard to say the least, and in our experience is largely through word of mouth or after directly contacting mammalogists. We encourage professional biologists seeking volunteers for help with field work to contact the mammalwatching community.

\section{More access for mammalwatchers}

One issue of great importance to mammalwatchers is access. In recent years, many protected natural areas worldwide have introduced stricter limitations on nighttime and/or unguided access. For example, almost all national wildlife refuges in the USA are now open only during daylight hours (Dinets, 2015).

Spotlighting is often prohibited; this rule is usually introduced to combat nighttime poaching, but it is often interpreted as a ban on any use of flashlights (www.yellowstonepark.com/yellowstone-regulations/).

These practices can make mammalwatching difficult or impossible, since many species of mammals are nocturnal and finding them requires silence, which is often problematic in the presence of an unprofessional guide. Organized night drives and guided walks, when available, can be expensive, as in many Indonesian national parks (VD pers. obs.), or focus only on the larger and more charismatic species, with vehicles often not stopping to look at smaller mammals (JH pers. obs.). These rules have resulted in drops in visitation by mammalwatchers, for example, in Corcovado National Park in Costa Rica (Fletcher, 2013).

Indeed some guides of mammalwatching tours now try to avoid national parks and visit private and community reserves with fewer access restrictions (R. Cassidy personal communication). The situation is particularly pronounced in many African parks, where visitors have to remain in fenced camps from sunset to sunrise, supposedly for their own safety. The parks where strict "safety" rules are not applied, such as Mana Pools in Zimbabwe where the campsite is unfenced and people are allowed to walk anywhere, at their own risk, actually have a better safety record than those where "safety" rules are the strictest (Bechky, 1997). Not surprisingly, a recent survey of visitors to Mana Pools National Park has shown that the majority of them chose to visit that park precisely because it allows unlimited unguided walking (The Zambezi Society, 2015).Where mammal watching at night is allowed, its impact on wildlife is minimal (Newsome et al. 2005); or at least there is no evidence to the contrary.

Considering the growing importance of mammalwatching as a source of visitor funding and citizen science, the administrators of protected natural areas should consider formulating their rules to ensure 
mammalwatching is encouraged and suitably managed, for example, by making it possible for responsible mammalwatchers to be exempted from some restrictions or by helping them obtain special use permits.

\section{CONCLUSION}

It is time to recognize the benefits mammalwatching can bring to science and conservation, and to make sure that the relationship between amateurs and professionals is mutually beneficial. Current dynamics show that mammalwatching has a great potential; the future will show if it becomes as important and beneficial as birding, which we think is entirely possible.

\section{CONFLICT OF INTERESTS}

The authors have not declared any conflict of interests.

\section{REFERENCES}

Andrew D (2016). The Complete Guide to Finding the Mammals of Australia. Clayton, Australia: CSIRO Publishing.

Balmford A (2013). Balmford trip report: Australia and Singapore 9 July11 Sept. $2013 . \quad$ URL: http://mammalwatching.com/Australasian/Otherreports/AB\%20Austra lia\%202013.pdf

Balmford A, Beresford J, Green J, Naidoo R, Walpole M, Manica A (2009). A global perspective on trends in nature-based tourism. PLoS Biology 7(6):e1000144.

Bechky A (1997). Adventuring in Southern Africa: The Great Safaris and Wildlife Parks of Botswana, Zimbabwe, Zambia, Namibia, South Africa, Malawi, Lesotho, and Swaziland. San Francisco: Sierra Club Books.

Ben-Yehuda T (2018). Records of mountain weasel in Ladakh, India. In press, Small Carnivore Conservation.

Buckley R (2003). Case Studies in Ecotourism. Wallingford, UK: The Centre for Biosciences and Agriculture International.

Christie IT, Crompton DE (2001). Tourism in Africa. Washington, DC: World Bank.

Clarke R (2016). Some notes on mammal watching in SW Western Australia Oct-Nov 2016. URL: http://www.mammalwatching.com/wpcontent/uploads/2016/12/RC-Mammal-watching-in-SW-WA.pdf.

Cordell HK, Herbert NG (2012). The popularity of birding is still growing. Birding pp. 54-61.

Czeszczewik D, Walankiewicz W (2017). Effect of logging on birds and local economy in the Białowieza Forest, Poland. Proceedings of the 11th Conference of the European Ornithologists' Union, $18-22$ August 2017, Turku, Finland.

De Silva GH, Reyes AE (2010). Breve historia de la observación de aves en México en el siglo XX y principios del siglo XXI. Huitzil 11:920.

Desai S (2016). The snow leopard's ascent. URL: http://www.livemint.com/Leisure/IVh9SILmOZ0pPqhQakS5sJ/Thesnow-leopards-ascent.html

Dinets V (2015). Peterson Guide to Finding Mammals in North America. Boston: Houghton Mifflin Harcourt.

Dinets V (2016). Long-term cave roosting in the spectral bat (Vampyrum spectrum). Mammalia 81:529-531.

Dinets V (2017) Surface foraging in Scapanus moles. Mammalia 82:4853.
Dinets V, de Beenhower M, Hall J (2015). Extralimital records of pallid and Rueppell's foxes from Afar Desert of Ethiopia. Canid Biol. Conservation 19:1-3.

Dunlap TR (2011). In the Field, Among the Feathered: A History of Birders \& Their Guides. Oxford, UK: Oxford University Press.

Eaton JA, Wüst R, Wirth R, Shepherd CR, Semiadi G, Hall J, Duckworth JW (2010). Recent records of the Javan small-toothed palm civet Arctogalidia (trivirgata) trilineata. Small Carnivore Conservation 43:16-22.

Estes RD (1999). The Safari Companion: a Guide to Watching African Mammals. White River Junction, Vermont, USA: Chelsea Green Publishing.

Fletcher R (2013). Between the cattle and the deep blue sea. In: The Ecotourism-extraction Nexus: Political Economies and Rural Realities of (Un)comfortable Bedfellows, eds. B. Büscher, B \& S. Davidov, London: Routledge. pp. 69-87.

Foley C (2005). A big mammal day. Birding pp. 61-62.

Greenwood JJD (2007). Citizens, science and bird conservation. J. Ornithol. 148:77-124.

Higginbottom K (2004). Wildlife Tourism. Altona, Victoria: Common Ground.

Hirschfeld E, Swash A, Still R (2013). The World's Rarest Birds. Princeton, USA: Princeton University Press.

Hosner PA, Boggess NC, Alviola P, Sanchez-Gonzalez LA, Oliveros $\mathrm{CH}$, Urriza R, Moyle RG (2013). Phylogeography of the Robsonius ground-warblers (Passeriformes: Locustellidae) reveals an undescribed species from northeastern Luzon, Philippines. The Condor 115:630-639.

International Union for Conservation of Nature (IUCN) (2014). The IUCN Red List of Threatened Species. Version 2014.3. URL: http://www.iucnredlist.org (Accessed July 2017).

Kylie P, Quinn MS, Huijser MP, Graham J, Broberg L (2014). An evaluation of a citizen science data collection program for recording wildlife observations along a highway. J. Environ. Manag. 139:180187.

La Rouche PG (2003). Birding in the United States: a demographic and economic analysis. Addendum to the 2001 National Survey of Fishing, Hunting and Wildlife-Associated Recreation. Report 2001-1. Arlington, Virginia: U.S. Fish and Wildlife Service.

Matson JO, Ordóñez-Garza N, Bulmer W, Eckerlin RP (2012). Comunidades de pequeños mamíferos en la Sierra de los Cuchumatanes, Huehuetenango, Guatemala. Mastozoología Neotropical 19:71-84.

Moores R (2007). Where to Watch Mammals in Britain and Ireland. London: A \& C Black.

Moss S (2004). A Bird in the Bush: A Social History of Birdwatching. London: Aurum Press.

Newell J (2015). The Russian Far East: a Reference Guide for Conservation and Development. McKinleyville, CA: Daniel \& Daniel.

Newsome D, Dowling RK, Moore SA (2005). Wildlife Tourism. Bristol, UK: Channel View Publications.

Novacek MJ (2008). Engaging the public in biodiversity issues. Proceed. Natl. Acad. Sci. 105(S1):11571-11578.

Novacovic J, Das S (2006). In Search of the Pangolin: Eco-travel Tales. Sydney, Australia: New Holland Publishers.

Pitman RL, Deecke VB, Gabriele CM, Srinivasan M, Black N, Denkinger J, Durban JW, Mathews EA, Matkin DR, Neilson JL, SchulmanJaniger A (2017). Humpback whales interfering when mammal-eating killer whales attack other species: Mobbing behavior and interspecific altruism? Mar. Mamm. Sci. 33:7-58.

Racey PA (2013). Bat conservation: past, present and future. In: Bat Evolution, Ecology, and Conservation New York: Springer, pp. 517532.

Sekercioglu CH (2002). Impacts of birdwatching on human and avian communities. Environ. Conserv. 29:282-289.

Scholes RJ, Biggs R (2004). Ecosystem Services in Southern Africa: a Regional Perspective. Pretoria, South Africa: Council for Scientific and Industrial Research. 
Sullivan BL, Wood CL, lliff MJ, Bonney RE, Fink D, Kelling S (2009). eBird: a citizen-based bird observation network in the biological sciences. Biol. Conserv. 142:2282-2292.

The Zambezi Society (2015). National Parks reinstates "unguided" public walking in Mana Pools. URL: http://www.zamsoc.org/?p=2045. (Accessed on July 6, 2017).

Thiel M, Penna-Díaz MA, Luna-Jorquera G, Salas S, Sellanes J, Stotz W (2014). Citizen scientists and marine research: volunteer participants, their contributions, and projection for the future. Oceanography and Marine Biology: An Annual Review 52:257-314.

Whitaker JO (1996). National Audubon Society Field Guide to North American Mammals. New York: Alfred A. Knopf.
Wilson DE, Mittermeier RA (2014). Handbook of the Mammals of the World. Vol. 4. Sea Mammals. Barcelona: Lynx Edicions.

Woolgar J (2014). A confirmed sighting of Pousargues's mongoose Dologale dybowskii. Small Carnivore Conservation 51:1-3.

World Bank (2017). Sierra Leone.

http://data.worldbank.org/country/sierra-leone

URL: 